\title{
Fermentative degradation of putrescine by new strictly anaerobic bacteria
}

\author{
Carola Matthies ${ }^{1}$, Frank Mayer ${ }^{2}$, and Bernhard Schink ${ }^{1}$ \\ 1 Lehrstuhl Mikrobiologie I, Eberhard-Karls-Universität, Auf der Morgenstelle 28, D-7400 Tübingen, Federal Republic of Germany \\ 2 Institut für Mikrobiologie, Georg-August-Universität, Grisebachstrasse 8, D-3400 Göttingen, Federal Republic of Germany
}

\begin{abstract}
Three strains of new strictly anaerobic, Grampositive, non-sporeforming bacteria were isolated from various anoxic sediment samples with putrescine as sole carbon and energy source. Optimal growth in carbonate-buffered defined medium occurred at $37^{\circ} \mathrm{C}$ at $\mathrm{pH} 7.2-7.6$. The DNA base ratio of strain NorPut1 was $29.6 \pm 1 \mathrm{~mol} \%$ guanine plus cytosine. In addition to a surface layer and the peptidoglycan layer, the cell wall contained a second innermost layer with a periodic arrangement of subunits. All strains fermented putrescine to acetate, butyrate, and molecular hydrogen; the latter originated from both oxidative putrescine deamination and 4-aminobutyraldehyde oxidation. In defined mixed cultures with methanogens or homoacetogenic bacteria, methane or additional acetate were formed due to interspecies hydrogen transfer. Also 4-aminobutyrate and 4-hydroxybutyrate were fermented to acetate and butyrate, but no hydrogen was released from these substrates. No sugars, organic acids, other primary amines or amino acids were used as substrates. Neither sulfate, thiosulfate, sulfur, nitrate nor fumarate was reduced. Most of the enzymes involved in putrescine degradation could be demonstrated in cell-free extracts. A pathway of putrescine fermentation via 4-aminobutyrate and crotonyl$\mathrm{CoA}$ with subsequent dismutation to acetate and butyrate is suggested.
\end{abstract}

Key words: Anaerobic degradation - Primary amine oxidation - Cell wall structure - Putrescine - Interspecies hydrogen transfer - Diamines

Primary aliphatic amines are formed during oxygen-limited decomposition of organic matter rich in protein. Clostridia and some enterobacteria produce biogenic amines, e.g., putrescine or cadaverine, by decarboxylation of the respective amino acids (Brock 1979; Knoke and Bernhardt 1985). These putrid-smelling and often highly toxic compounds ("ptomaines") are also released in food, e.g., in ripening cheese (Lindner 1986).

In natural environments, primary amines do not accumulate, but few is known about their decomposition. Aerobic degradation starts with oxidative deamination by amine oxidases as described for the inactivation of biogenic amines in vertebrates (Karlson 1984), leading to the respective aldehyde, ammonia, and $\mathrm{H}_{2} \mathrm{O}_{2}$ as products. Another

Offprint requests to: C. Matthies way of elimination of the $\mathrm{NH}_{2}$-group is transamination as described for a putrescine-degrading mutant of Escherichia coli: Putrescine is degraded by a putrescine: 2 -oxoglutaratetransaminase and a dehydrogenase to form 4-aminobutyrate which is further metabolized through succinate via the citric acid cycle (Prieto-Santos et al. 1986).

Anaerobic degradation of primary amines by fermenting bacteria could follow a basically similar route, and dispose of the released reducing equivalents in a similar manner as described for primary aliphatic alcohols. In the absence of external electron acceptors such as sulfate or nitrate, incomplete oxidation to fatty or dicarboxylic acids could be coupled to syntrophic methane formation, homoacetogenesis, or reductive synthesis of long-chain fatty acids. It was of general interest to find out whether the fermentative degradation of primary amines takes comparable routes.

In the present study, new isolates of strictly anaerobic bacteria are described which degrade putrescine fermentatively and form acetate, butyrate, and $\mathrm{H}_{2}$ as products. Enzymes involved in putrescine degradation were measured, and a catabolic pathway is proposed.

\section{Materials and methods}

Sources of organisms

Three strains were isolated in pure culture from enrichment cultures inoculated with mud samples:

Strain NorPut1 from anoxic brackish water sediment of the estuary of the Norsminde fjord near Aarhus, Denmark.

Strain FrPut1 from anoxic mud of a polluted ditch near Konstanz, FRG.

Strain MaPut1 from anoxic marine black mud of Rio Marin, a channel located in the city of Venice, Italy.

Methanospirillum hungatei strain $\mathrm{M} 1 \mathrm{~h}$ was isolated from digested anaerobic sludge of the sewage plant at Göttingen, FRG, and cultivated in freshwater medium with $5 \mathrm{mM}$ acetate under $\mathrm{H}_{2} / \mathrm{CO}_{2}$ gas mixture $(80 \% / 20 \%)$.

Desulfovibrio vulgaris strain Marburg was kindly provided by Prof. R. K. Thauer, Marburg, FRG.

Acetobacterium woodii (DSM 1030) was obtained from the Deutsche Sammlung für Mikroorganismen, Braunschweig, FRG.

\section{Media and growth conditions}

All procedures for cultivation and isolation were as previously described (Widdel and Pfennig 1981; Schink and Pfennig 1982; Schink 1984). The mineral salts medium for 
isolation and further cultivation was carbonate-buffered $(30 \mathrm{mM})$ and sulfide-reduced $(1 \mathrm{mM})$, and contained $1 \mathrm{ml}$ of selenite-tungstate solution and $1 \mathrm{ml}$ of trace element solution SL 10 (Widdel et al. 1983) per liter, as well as $0.5 \mathrm{ml} / 1$ of 7-vitamins solution (Widdel and Pfennig 1981). The $\mathrm{pH}$ was adjusted to 7.2-7.4. Growth experiments were carried out in $27 \mathrm{ml}$-serum tubes filled with medium, gassed with $\mathrm{N}_{2} /$ $\mathrm{CO}_{2}$ gas mixture $(90 \% / 10 \%)$, and sealed with butyl rubber stoppers. Growth was followed by measuring turbidity at $450 \mathrm{~nm}$ wavelength with a Spectronic 20 spectrophotometer (Milton Roy, NY, USA). All cultures were incubated at $30^{\circ} \mathrm{C}$

\section{Characterization of isolates}

Gram staining was carried out according to Bartholomew (1962). Acetobacterium woodii and Pelobacter acidigallici were used as controls.

Flagella were visualized by staining after Blenden and Goldberg (1965).

Spore formation was checked for after growth in freshwater medium with $20 \%$ soil extract and $5 \mathrm{mg} \mathrm{MnSO}_{4}$ per liter. Alternatively, $1.5 \%$ tryptone and $0.1 \%$ xylose were added as well (modified after Hollaus and Sleytr 1972).

Cytochromes were assayed in French press cell extracts of putrescine-grown cells. Crude extracts were subjected to difference spectroscopy in a Uvikon 860 spectrophotometer (Kontron, Zürich, Switzerland).

The DNA base composition was determined with the thermal denaturation method according to De Ley et al. (1970) after extraction according to Mandel et al. (1970). Escherichia coli strain B (NCTC 10537) was taken as reference.

For electron microscopic examinations, cell material was fixed, dehydrated, ultrathin-sectioned and post-stained as described (Walther-Mauruschat et al. 1977). Electron micrographs were taken with a Philips EM 301 electron microscope at calibrated magnifications.

\section{Chemical analyses}

Acetate, butyrate, and methane were assayed by gas chromatography as described (Platen and Schink 1987). Hydrogen was determined with a Carlo Erba Vega 6000 gas chromatograph with thermal conductivity detector and a steel column $(2 \mathrm{~m} \times 4 \mathrm{~mm})$ packed with $60 / 80$ mesh molecular sieve ( $5 \AA$, Serva, Heidelberg, FRG), detector temperature $130^{\circ} \mathrm{C}$, column temperature $50^{\circ} \mathrm{C}$, carrier gas nitrogen, $78 \mathrm{ml} / \mathrm{min}$.

Formation of sulfide from sulfate or sulfur was analyzed by the methylene blue method (Cline 1969). Ammonia formation was determined by indophenol formation with phenol and hypochlorite (Chaney and Marbach 1962). Formation of nitrite from nitrate was assayed by azo dye formation with sulfanilic acid and $\alpha$-naphthylamine (Procházková 1959). Fumarate reduction to succinate was assayed by scanning UV spectra in a Uvikon 860 spectrophotometer. Fumarate in $98 \% \mathrm{H}_{2} \mathrm{SO}_{4}$ has an absorption maximum at $220 \mathrm{~nm}$ whereas succinate does not absorb at this wavelength. Protein in crude cell extracts was determined by dye formation with $\mathrm{CuSO}_{4}$ in alkaline solution (modified after Zamenhoff 1957).

\section{Enzyme assays}

All enzyme assays were carried out with crude French press cell extracts of putrescine-grown cells under anoxic conditions using a spectrophotometer model 100-40 (Hitachi, Tokyo, Japan). Hydrogenase was assayed with methylviologen as electron acceptor and $\mathrm{H}_{2}$ as substrate (modified after Diekert and Thauer 1978). Phosphate acetyl transferase and acetate kinase were measured by standard methods (Bergmeyer 1974). In the acetate kinase assay, the $\mathrm{Mg}^{2+}$ concentration was increased to $5 \mathrm{mM}$. Butyrate kinase was assayed by the acetate kinase assay using butyrate as substrate. Crotonase was determined following the crotonyl$\mathrm{COA}$ absorption decrease at $263 \mathrm{~nm}$ (Moskowitz and Merrick 1969). $\beta$-keto thiolase was measured according to Lynen and Ochoa (1953) with a cell extract dialyzed against potassium phosphate buffer $(50 \mathrm{mM}, \mathrm{pH} 7.2$, reduced with $2.5 \mathrm{mM}$ dithioerythrite) to outdilute coenzyme A. 4-aminobutyraldehyde dehydrogenase was assayed photometrically with benzylviologen as electron acceptor and butyraldehyde as substrate (Odom and Peck 1981). 4-hydroxybutyrate dehydrogenase was measured photometrically by following the oxidation of NADH with succinicsemialdehyde. The assay mixture contained: potasium phosphate buffer, $\mathrm{pH}$ $7.2,50 \mathrm{mM}$; NADH, $0.3 \mathrm{mM}$; succinicsemialdehyde, $18 \mathrm{mM}$; cell extract with $0.01-0.03 \mathrm{mg}$ protein. The reaction was started by addition of succinicsemialdehyde. $\mathrm{Pu}-$ trescine: 2-oxoglutarate transaminase was assayed following the formation of a dye from o-aminobenzaldehyde and 4aminobutyraldehyde which is the product of the enzyme reaction (modified after Kim 1964; Holmstedt et al. 1961). Butyryl-CoA dehydrogenase was quantified by following the oxidation of NADH with crotonyl-CoA (modified after Tischer et al. 1979). 3-hydroxybutyryl-CoA dehydrogenase was determined as NADH oxidation with acetoacetyl-CoA according to Lynen and Ochoa (1953). Alternatively, this enzyme was measured by APAD reduction with different substrates (modified after Bergmeyer 1974). Butyryl-CoA: acetate $\mathrm{CoA}$ transferase was measured in a coupled enzyme assay using butyryl-CoA and acetate as substrates (modified after Hilpert et al. 1984). All enzyme assays were carried out with $0.01-0.1 \mathrm{mg}$ protein per assay. They were measured photometrically in a spectrophotometer model 100-40 (Hitachi, Tokyo, Japan).

\section{Chemicals}

All chemicals were of reagent grade quality and obtained from Fluka, Neu-Ulm; Merck, Darmstadt; Sigma, Deisenhofen, and Boehringer, Mannheim, FRG. Gases were obtained from Messer-Griesheim, Darmstadt, FRG.

\section{Results \\ Enrichment and isolation}

Enrichment cultures with saltwater, brackish water and freshwater medium $(50 \mathrm{ml})$ containing $10 \mathrm{mM}$ putrescine as substrate were inoculated with $5 \mathrm{ml}$ of anoxic mud from various sources. Gas production started after $1-4$ weaks. In subcultures on the same medium, turbidity developed within 3-8 days. After four transfers, isolation of putrescine-degrading bacteria was attempted in agar shake series in the absence or presence of a lawn of either Acetobacterium 


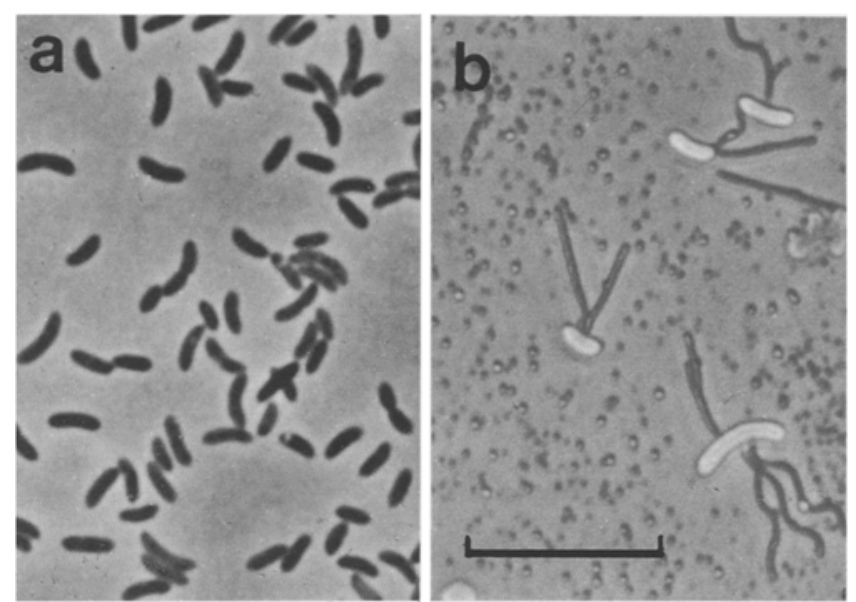

Fig. 1a, b. Phase contrast photomicrographs of strain NorPut1. a Vegetative cells; $\mathbf{b}$ vegetative cells with stained flagella. Bar equals $10 \mu \mathrm{m}$

woodii or Desulfovibrio vulgaris cells, the latter with sulfate as electron acceptor. In three cases lens-shaped, slightly yellowish colonies surrounded by small satellite colonies of the hydrogen-oxidizing partner bacteria developed which were again subjected to agar shake series dilution without the hydrogen oxidizing bacteria. Pure cultures were isolated from the last positive dilution tube (strains NorPut1, MaPut1, FrPut1). Purity was checked by microscopical control and by growth tests in AC medium (Difco, USA) in which only the isolated cell types were observed.

All three strains were morphologically very similar in size, shape, and Gram reaction, as well as in their physiological properties. Therefore, only one strain, NorPut1, was chosen for further characterization.

\section{Characterization of the brackish water isolate NorPutl}

Cytological properties. The cells of strain NorPut1 were slightly curved rods, $0.7-0.8 \times 1.9-2.7 \mu \mathrm{m}$ in size, with rounded ends (Fig. 1 a). Motility could only be observed in growing cultures. The cells moved in a tumbling manner by 3 - 5 flagella which were inserted on the concave side of the cell (Fig. 1b). Strain NorPut1 stained Gram-negative, but the $\mathrm{KOH}$ test showed no slime formation, a reaction typical of Gram-positive bacteria.

Electron microscopic examination of ultrathin sections of the cells indicated that no outer membrane typical of the cell wall of Gram-negative bacteria existed (Fig. 2a). The cell wall was seen to consist of a surface layer (SL) (Sleytr 1976; Sleytr and Glauert 1982) covered by unstructured amorphous electron-dense material (OL) (Sleytr et al. 1988) (Fig. 2a, c). The surface layer (SL) appeared to be attached to a thin electron-dense layer (DL) (Fig. 2c) probably representing the peptidoglycan layer of the wall (Wahlberg et al. 1987). An unusual feature of the cell wall was the occurrence of a second, innermost wall layer (BL) (Fig. 2a, b, d, e) exhibiting a periodic arrangement of subunits (SUB) (Fig. 2b, e) similar in size to those (SUS) (Fig. 2b, c, d) of the surface layer (SL).

Spore formation could never be observed, neither in defined medium nor in special sporulation media. The guanine-plus-cytosine content of the DNA of the strain NorPut1 was $29.6 \pm 1.0 \mathrm{~mol} \%$. No cytochromes could be detected in redox difference spectra of crude cell extracts.

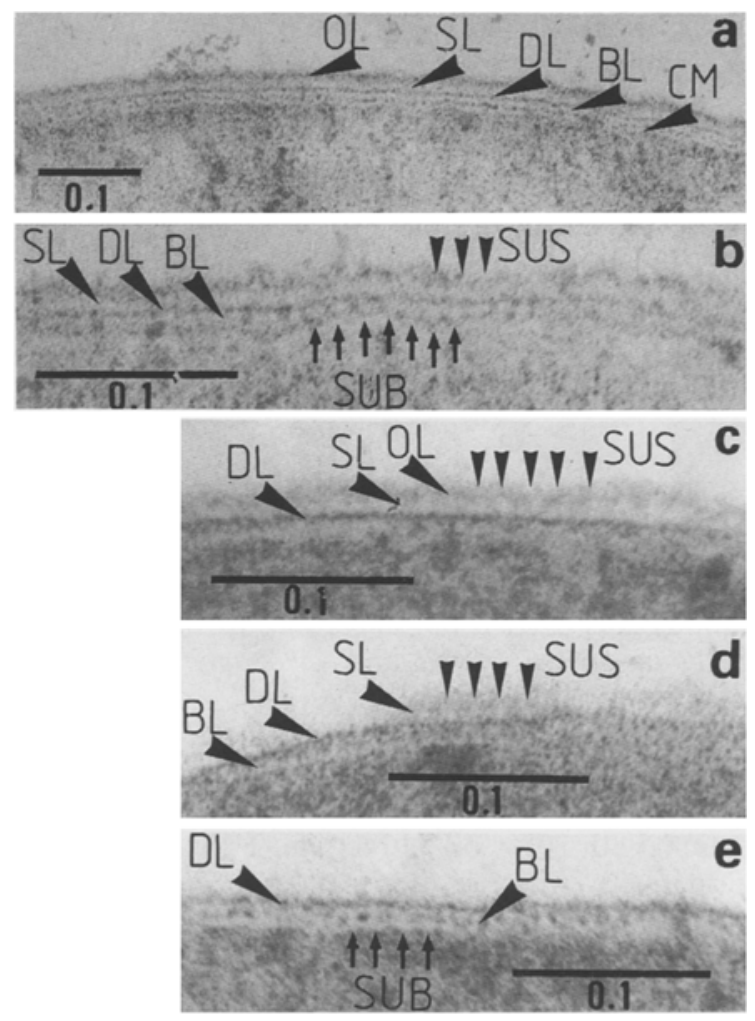

Fig. 2a-e. Ultrathin sections exhibiting cell envelope structures. $B L$ bright (electron-translucent) wall layer; $C M$ cytoplasmic membrane; $D L$ inner dark (electron-dense) wall layer; $O L$ outermost (electron-dense) wall layer; $S L$ periodic surface layer; $S U B$ periodically arranged subunits in $B L ; S U S$ periodically arranged subunits in $S L$. a The cell envelope contains several wall layers. b Subunits of similar size can be seen both in the surface layer and in an inner wall layer $(B L)$. These two wall layers are separated by a thin dark wall layer $(D L)$. c Surface layer with subunits (covered by the outermost electron-dense layer) and inner dark layer are visible. d and e Cells seen in ultrathin sections often showed partial (d) or complete (e) removal of the periodic surface layer $(S L)$. Bars refer to sizes in $\mu \mathrm{m}$

Physiology. Strain NorPut1 grew well in freshwater mineral medium and in saltwater medium containing up to $2 \% \mathrm{NaCl}$ and $0.3 \% \mathrm{MgCl}_{2} \times 6 \mathrm{H}_{2} \mathrm{O}(\mathrm{w} / \mathrm{v})$. Phosphate concentrations up to $50 \mathrm{mM}$ were tolerated. For growth in the defined medium, no supplines other than vitamines were required. In the presence of $0.05 \%$ yeast extract, the cells grew faster and the cell yield increased by $20 \%$. No growth occurred with yeast extract alone. The highest cell densities were obtained with $30 \mathrm{mM}$ putrescine. Optimal growth $(\mu=$ $0.044 \mathrm{~h}^{-1}, t_{\mathrm{d}}=16 \mathrm{~h}$ ) occurred at $37^{\circ} \mathrm{C}$, the temperature limits were $12^{\circ} \mathrm{C}$ and $50^{\circ} \mathrm{C}$. The $\mathrm{pH}$-optimum was at $\mathrm{pH}$ $7.2-7.6$; weak growth was still possible at $\mathrm{pH} 5.1$ and 8.0.

The only substrates degraded were putrescine, 4-aminobutyrate, and 4-hydroxybutyrate. Neither sugars, amino acids, organic acids, alcohols, nor other amines were used (Table 1). Neither nitrate, sulfate, sulfur, thiosulfate, nor fumarate could be used as electron acceptor during putrescine fermentation. Externally added electron donors, e.g. $\mathrm{H}_{2}$ or formate, were not oxidized during the fermentation of 4-aminobutyrate or putrescine. Products of putrescine fermentation were acetate, butyrate and molecular hydrogen. During fermentation of 4-aminobutyrate and 4hydroxybutyrate, only acetate and butyrate were formed. 
Table 1. Stoichiometry of fermentation and growth yields of strains NorPut1 and MaPut1

\begin{tabular}{|c|c|c|c|c|c|c|c|c|c|c|}
\hline \multirow[t]{2}{*}{ Substrate } & \multirow{2}{*}{$\begin{array}{l}\text { Substrate } \\
\text { degraded }^{\mathrm{c}} \\
(\mu \mathrm{mol})\end{array}$} & \multirow{2}{*}{$\begin{array}{l}\text { Optical } \\
\text { density } \\
\text { reached } \\
\Delta \mathrm{E}_{450}\end{array}$} & \multirow{2}{*}{$\begin{array}{l}\text { Cell dry } \\
\text { mass } \\
\text { formed }^{a} \\
(\mathrm{mg})\end{array}$} & \multirow{2}{*}{$\begin{array}{l}\text { Substrate } \\
\text { assimilated }^{b} \\
\text { ( } \mu \mathrm{mol})\end{array}$} & \multicolumn{4}{|c|}{ Products formed $(\mu \mathrm{mol})$} & \multirow{2}{*}{$\begin{array}{l}\text { Electron } \\
\text { recovery } \\
(\%)\end{array}$} & \multirow{2}{*}{$\begin{array}{l}\text { Molar } \\
\text { growth } \\
\text { yield } \\
(\mathrm{g} / \mathrm{mol}\end{array}$} \\
\hline & & & & & Acetate & Butyrate & $\mathrm{H}_{2}$ & Ammonia & & \\
\hline \multicolumn{11}{|l|}{ Strain NorPut1 } \\
\hline $\begin{array}{l}\text { 4-Amino- } \\
\text { butyrate } \\
\text { 4-Hydroxy- }\end{array}$ & 103.0 & 0.14 & 0.21 & 1.9 & 110 & 41 & 0 & 103 & 93.9 & 2.1 \\
\hline butyrate & $100.0^{\mathrm{d}}$ & 0.15 & 0.23 & 2.1 & 112 & 42 & 2 & - & 99.0 & 2.3 \\
\hline \multicolumn{11}{|l|}{ Strain MaPutl } \\
\hline $\begin{array}{l}\text { Putrescine } \\
\text { 4-Amino- }\end{array}$ & 93.5 & 0.31 & 0.68 & 5.2 & 22 & 77 & 119 & 187 & 98.0 & 7.3 \\
\hline $\begin{array}{c}\text { butyrate } \\
\text { 4-Hydroxy- }\end{array}$ & 112.0 & 0.23 & 0.50 & 4.6 & 122 & 43 & 0 & 112 & 96.0 & 4.5 \\
\hline butyrate & $100.0^{c}$ & 0.22 & 0.48 & 4.4 & 110 & 39 & 0 & - & 97.6 & 4.8 \\
\hline
\end{tabular}

Experiments were carried out in $27 \mathrm{ml}$ serum tubes filled with $10 \mathrm{ml}$ culture, headspaces gassed with $\mathrm{N}_{2} / \mathrm{CO}_{2}$ gas mixture $(90 \% / 10 \%)$

${ }^{a}$ Cell dry matter was calculated via cell turbidity using the conversion factors $0.1 \mathrm{OD}_{450}=16 \mathrm{mg}$ dry matter per liter (NorPut1) and 0.1 $\mathrm{OD}_{450}=23 \mathrm{mg}$ dry matter per liter (MaPut1), which were obtained by direct gravimetric determinations in $500 \mathrm{ml}$ cultures grown with putrescine

${ }^{b}$ Substrate assimilated was calculated using the formula $\left(\mathrm{C}_{4} \mathrm{H}_{8} \mathrm{O}_{2} \mathrm{~N}\right)$ for cell material

- Substrate degraded was calculated by determination of ammonia formed

d Substrate added

The following substrates were not degraded by strain NorPut 1 in the presence of $5 \mathrm{mM}$ acetate (if not indicated otherwise, the substrates were added to $10 \mathrm{mM}$, sugars to $5 \mathrm{mM}$ ): 1,3-diaminopropane, cadaverine, $\beta$-alanine, ethylamine, ethylenediamine, ethanolamine, methylamine $(5 \mathrm{mM})$, betaine, choline, aniline $(2 \mathrm{mM})$, casamino acids $(0.1 \%)$, glycine, glucose, fructose, arabinose, xylose, glucosamine, lactose, sucrose, formate, lactate, malate, fumarate, succinate, oxalate $(4 \mathrm{mM})$, malonate, glycerol, 1,4-butanediol, 1,3-propanediol, methanol (5 $\mathrm{mM})$, $\mathrm{H}_{2} /$ $\mathrm{CO}_{2}(80 \% / 20 \%)$. Degradation of ethylamine, ethyleneamine, methylamine, aniline, and amino acids was tested also in the presence of $\mathrm{H}_{2}$ as external electron donor

\section{Growth yields and stoichiometry}

The stoichiometry of substrate utilization was measured with all three strains isolated. The results obtained with strain NorPut1 and strain MaPut1 are presented in Table 1. The values obtained with strain FrPut1 were similar to those with strain NorPut1. The amounts of fermentation products agreed with complete conversion of the substrates according to the following equation:

Putrescine:

\section{Strain NorPut1}

$10 \mathrm{H}_{3} \mathrm{NCH}_{2}\left(\mathrm{CH}_{2}\right)_{2} \mathrm{CH}_{2} \mathrm{NH}_{3}{ }^{2+}+26 \mathrm{H}_{2} \mathrm{O}$

$\rightarrow 6 \mathrm{CH}_{3} \mathrm{COO}^{-}+7 \mathrm{CH}_{3}\left(\mathrm{CH}_{2}\right)_{2} \mathrm{COO}^{-}+20 \mathrm{NH}_{4}^{+}$

$+16 \mathrm{H}_{2}+13 \mathrm{H}^{+}$

Strain MaPut1

$$
\begin{aligned}
20 \mathrm{H}_{3} \mathrm{NCH}_{2}\left(\mathrm{CH}_{2}\right)^{2} \mathrm{CH}_{2} \mathrm{NH}_{3}{ }^{2+}+46 \mathrm{H}_{2} \mathrm{O} \\
\rightarrow 6 \mathrm{CH}_{3} \mathrm{COO}^{-}+17 \mathrm{CH}_{3}\left(\mathrm{CH}_{2}\right)_{2} \mathrm{COO}^{-} \\
\quad+40 \mathrm{NH}_{4}{ }^{+}+26 \mathrm{H}_{2}+23 \mathrm{H}^{+}
\end{aligned}
$$

4-Aminobutyrate:

Both strains

$2 \mathrm{H}_{3} \mathrm{NCH}_{2}\left(\mathrm{CH}_{2}\right)_{2} \mathrm{COO}+2 \mathrm{H}_{2} \mathrm{O} \rightarrow$

$2 \mathrm{CH}_{3} \mathrm{COO}^{-}+1 \mathrm{CH}_{3}\left(\mathrm{CH}_{2}\right)_{2} \mathrm{COO}^{-}+2 \mathrm{NH}_{4}{ }^{+}+1 \mathrm{H}(3)$

4-Hydroxybutyrate:

Both strains

$$
\begin{aligned}
& 2 \mathrm{HOCH}_{2}\left(\mathrm{CH}_{2}\right)_{2} \mathrm{COO}^{-}+2 \mathrm{H}_{2} \mathrm{O} \\
& \rightarrow 2 \mathrm{CH}_{3} \mathrm{COO}^{-}+1 \mathrm{CH}_{3}\left(\mathrm{CH}_{2}\right)_{2} \mathrm{COO}^{-}+1 \mathrm{H}^{+}
\end{aligned}
$$

\section{Effect of hydrogen on putrescine fermentation}

Experiments in defined mixed cultures were carried out with strain NorPut1 and either Acetobacterium woodii or Methanospirillum hungatei as hydrogen-scavening partner organism. The results obtained are summarized in Table 2. In mixed cultures with hydrogen-oxidizing bacteria the putrescine fermentation pattern of strain NorPut1 changed. No hydrogen was formed, and acetate to butyrate ratio was $2: 1$ as compared to $6: 7$ in pure culture. Putrescine degradation in mixed cultures agreed with the following equations:

$$
\begin{aligned}
2 & \mathrm{H}_{3} \mathrm{NCH}_{2}\left(\mathrm{CH}_{2}\right)_{2} \mathrm{CH}_{2} \mathrm{NH}_{3}{ }^{2+}+2 \mathrm{HCO}_{3}^{-}+2 \mathrm{H}_{2} \mathrm{O} \\
\rightarrow & 3 \mathrm{CH}_{3} \mathrm{COO}^{-}+1 \mathrm{CH}_{3}\left(\mathrm{CH}_{2}\right)_{2} \mathrm{COO}^{-} \\
& +4 \mathrm{NH}_{4}^{+}+2 \mathrm{H}^{+}
\end{aligned}
$$

$$
\begin{aligned}
2 \mathrm{H}_{3} \mathrm{NCH}_{2}\left(\mathrm{CH}_{3}\right)_{2} \mathrm{CH}_{2} \mathrm{NH}_{3}{ }^{2+}+1 \mathrm{HCO}_{3}{ }^{-}+3 \mathrm{H}_{2} \mathrm{O} \\
\rightarrow 2 \mathrm{CH}_{3} \mathrm{COO}^{-}+1 \mathrm{CH}_{3}\left(\mathrm{CH}_{2}\right)_{2} \mathrm{COO}^{-} \\
\quad+1 \mathrm{CH}_{4}+4 \mathrm{NH}_{4}^{+}+2 \mathrm{H}^{+}
\end{aligned}
$$

Excess hydrogen added to a culture of strain NorPut1 growing with putrescine delayed and inhibited growth considerably (Fig. 3).

\section{Enzymes involved in putrescine degradation}

Enzymes were assayed in crude cell extracts prepared from putrescine-grown cells of strain NorPut1. Hydrogenase, 4-aminobutyraldehyde dehydrogenase, 4-hydroxybutyrate dehydrogenase, acetate kinase, phosphate acetyl transferase, 
Table 2. Growth yields and stoichiometry of putrescine fermentation by strain NorPut1 in coculture with Acetobacterium woodii or Methanospirillum hungatei

\begin{tabular}{|c|c|c|c|c|c|c|c|}
\hline \multirow[t]{2}{*}{ Co-organism } & \multirow{2}{*}{$\begin{array}{l}\text { Putrescine } \\
\text { degraded } \\
(\mu \mathrm{mol})\end{array}$} & Acetate & Butyrate & Methane & Ammonia & \multirow{2}{*}{$\begin{array}{l}\text { Electron } \\
\text { recovery } \\
(\%)\end{array}$} & \multirow{2}{*}{$\begin{array}{l}\text { Growth yield } \\
\text { (g/mol } \\
\text { putrescine } \\
\text { utilized) }\end{array}$} \\
\hline & & $(\mu \mathrm{mol})$ & & & & & \\
\hline A. woodii & 94.8 & 138 & 46 & - & 189.6 & 100 & 5.1 \\
\hline M. hungatei & 468.0 & 499 & 205 & 396 & 936.0 & 110 & 2.6 \\
\hline
\end{tabular}

Experiments with Acetobacterium woodii were carried out as described in Table 1 whereas the experiments with Methanospirillum hungatei were run in half-filled $100 \mathrm{ml}$ serum bottles, the headspace gassed with $\mathrm{N}_{2} / \mathrm{CO}_{2}$ gas mixture $(90 \% / 10 \%)$

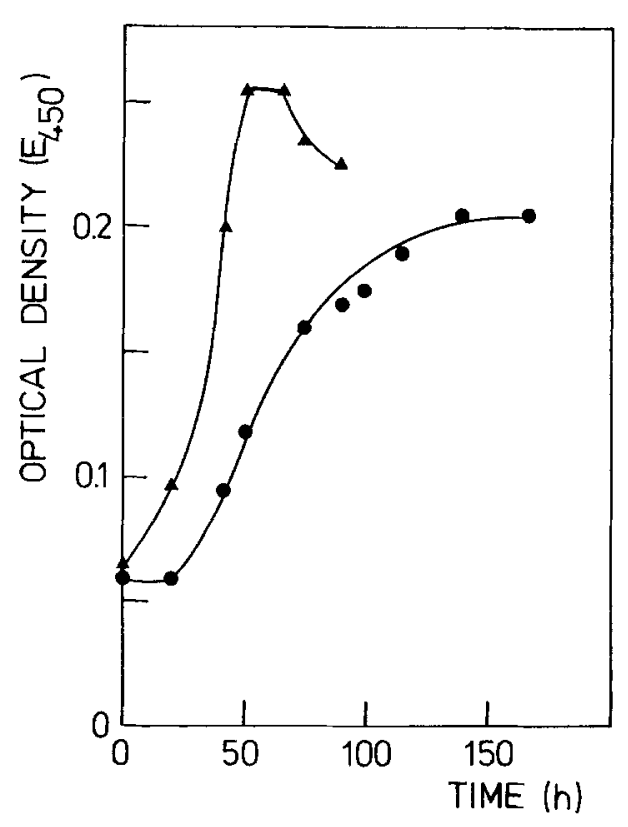

Fig. 3. Effect of excess hydrogen on putrescine fermentation by strain NorPut1. Experimental conditions are described in Table 1. (ム) growth under $\mathrm{N}_{2} / \mathrm{CO}_{2} ;(\bullet)$ growth under $\mathrm{H}_{2} / \mathrm{CO}_{2} ; \mathrm{OD}_{450}$ optical density at $450 \mathrm{~nm}$

crotonase, $\beta$-ketothiolase and butyryl-CoA:acetate CoA transferase showed activities sufficient for involvement in dissimilatory metabolism (Table 3 ). The activity of 4aminobutyraldehyde dehydrogenase could not be enhanced by adding coenzyme A. Putrescine:2-oxoglutarate aminotransferase, butyryl-CoA dehydrogenase and 3-hydroxybutyryl-CoA dehydrogenase were detected at low activities (Table 3) as well as NAD-dependent 3-hydroxybutyryl-CoA dehydrogenase measured with APAD and vinylacetate as substrates in the presence of acetyl-CoA $\left(0.032 \mu \mathrm{mol} \cdot \mathrm{min}^{-1}\right.$ - $\mathrm{mg}$ protein ${ }^{-1}$ ). For the latter enzyme, no activity was detected with crotonate, crotonyl-CoA and 3-hydroxybutyryl-CoA. Putrescine:2-oxoglutarate aminotransferase, butyryl-CoA dehydrogenase and NAD-dependent 3hydroxybutyryl-CoA dehydrogenase (with APAD and vinylacetate) did not exhibit significant catabolic activities and showed no linear relationship between activity and the amount of protein added. Carbon monoxide dehydrogenase and butyrate kinase could not be detected.

\section{Discussion \\ Physiology}

In the present study, three strains of putrescine-fermenting bacteria were enriched and isolated from marine, brackish, and limnic anoxic sediment samples. They all were bacteria typical of an estuarine environment where salt concentrations change periodically, and they all tolerate concentrations up to $2 \% \mathrm{NaCl}$ and $0.3 \% \mathrm{MgCl}_{2}(\mathrm{w} / \mathrm{v})$. Nonetheless, their optimal growth temperature was at $37^{\circ} \mathrm{C}$ indicating that they could as well be typical inhabitants of the intestinal system of warm-blooded higher animals where primary amines are common substrates. The range of substrates used as sole carbon and energy source was very small: only putrescine, 4-aminobutyrate and 4-hydroxybutyrate were used, and were fermented to acetate, butyrate and, in the case of putrescine, also molecular hydrogen. Thus, putrescine is not syntrophically oxidized to the corresponding dicarboxylic acid succinate as originally expected, but dismutated to acetate, butyrate, and hydrogen, by a pure culture.

The pathway of substrate degradation was analyzed with strain NorPut1 by enzyme measurements in cell-free extracts. The results are summarized in a hypothetical degradation pathway (Fig. 4). Putrescine:2-oxoglutarate aminotransferase and 4-aminobutyraldehyde dehydrogenase were detected which oxidize putrescine to 4-aminobutyrate. 4-Aminobutyraldehyde oxidation was coupled to benzylviologen reduction and was independent of coenzyme A in our test system. ATP synthesis coupled to this oxidation step has to be postulated on the basis of cell yield measurements (see below), however, the mechanism involved remains unclear at present.

Oxidative deamination of 4-aminobutyrate would lead to succinicsemialdehyde which is reduced to 4-hydroxybutyrate by a very active dehydrogenase. The further degradation involves dehydration and activation to the CoA derivative, and isomerization to crotonyl-CoA. Unfortunately, we were unable to detect the respective enzyme activities and it remains unclear whether isomerization of the vinylacetylCoA to the crotonyl residue occurs with the free acids or their CoA derivatives. A vinylacetyl-CoA: crotonyl-CoA isomerase was reported to be active in 4-aminobutyrate degradation by Clostridium aminobutyricum (Hardman and Stadtman 1963), and in ethanol-acetate fermentation by Clostridium kluyveri (Bartsch and Barker 1961). In extracts of strain NorPut1, an NAD-dependent 3-hydroxybutyrylCoA dehydrogenase activity could be proven with 
Table 3. Enyzmes involved in putrescine degradation by strain NorPut1

\begin{tabular}{|c|c|c|}
\hline Enzyme & EC number & $\begin{array}{l}\text { Specific activity } \\
\left(\mu \mathrm{mol} \cdot \min ^{-1}\right. \\
\left.\mathrm{mg}^{-1} \operatorname{protein}^{-1}\right)\end{array}$ \\
\hline Hydrogenase $^{\mathrm{a}}$ & 1.18 .99 .1 & 5.85 \\
\hline $\begin{array}{l}\text { 4-Aminobutyraldehyde } \\
\text { dehydrogenase }^{b}\end{array}$ & 1.2.1.19 & 1.44 \\
\hline 4-Hydroxybutyrate & & \\
\hline dehydrogenase $^{c}$ & 1.1.1.61 & 3.3 \\
\hline Acetate kinase & 2.7 .2 .1 & 0.44 \\
\hline Phosphate acetyl transferase & 2.3.1.8 & 4.2 \\
\hline Crotonase & 4.2.1.17 & 2.1 \\
\hline$\beta$-Ketothiolase & 2.3 .1 .19 & 2.9 \\
\hline $\begin{array}{l}\text { Butyryl-CoA:acetate } \mathrm{CoA} \\
\text { transferase }\end{array}$ & 2.8.3.8 & 1.05 \\
\hline $\begin{array}{l}\text { Putrescine:2-oxoglutarate } \\
\text { aminotransferase }\end{array}$ & $?$ & 0.061 \\
\hline $\begin{array}{l}\text { Butyryl-CoA dehydrogenase } \\
\text { 3-Hydroxybutyryl-CoA }\end{array}$ & 1.3.99.2 & 0.028 \\
\hline dehydrogenase ${ }^{\mathrm{c}}$ & 1.1.1.157 & 0.06 \\
\hline
\end{tabular}

a Methylviologen-dependent

${ }^{b}$ Benzylviologen-dependent

c $\mathrm{NAD}^{+}$-dependent

vinylacetate, APAD, and acetyl-CoA as substrates indicating that vinylacetate is activated to its CoA derivative before isomerization by an acetyl-CoA: vinylacetate $\mathrm{CoA}$ transferase. Such an enzyme was also assumed to be active in succinate metabolism of Clostridium kluyveri (Stadtman 1953; Kenealy and Waselefsky 1985).

The further dismutation of the crotonyl residue to acetate and butyrate follows well-known reaction sequences which were all proven by demonstration of the respective enzyme activities in cell extracts. Unlike in Clostridium aminobutyricum, the CoA-group of butyryl-CoA is transferred to acetate with our strain by butyryl-CoA:acetate CoA transferase to form acetyl-CoA. Hydrogen was an important product of putrescine fermentation by all three isolates, but not of 4-aminobutyrate or 4-hydrxoybutyrate fermentation. Obviously, it is formed from the reducing equivalents released in oxidative deamination via glutamate as amino group carrier, and in aminobutyraldehyde oxidation to aminobutyric acid. The former ones arise at $E_{0}{ }^{\prime}=-110 \mathrm{mV}$, the latter at $E_{0}{ }^{\prime}<-500 \mathrm{mV}$. Whereas the low-potential electrons are quantitatively released as molecular hydrogen via a methylviologen-reducing hydrogenase, the former ones need an acceptor of a potential considerably higher than that of protons, and give rise to more butyrate instead of acetate formation [Table 1 and Eqs. $(1-4)$ ]. The ratio of butyrate over acetate fermentation depended considerably on the size of the culture headspace or on the presence of hydrogen-consuming partner organisms. How-

Fig. 4. Hypothetical pathway of putrescine degradation by strain NorPut1. Numbers in circles refer to the following enzymes which were detected in cell-free extracts: (1) putrescine:2-oxoglutarate aminotransferase; (2) 4-aminobutyraldehyde dehydrogenase; (3) hydrogenase; (4) 4-hydroxybutyrate dehydrogenase; (5) crotonylCoA dehydrogenase; (6) butyryl-CoA:acetate CoA transferase; (7) crotonase; (8) 3-hydroxybutyryl-CoA dehydrogenase; $(9) \beta$ ketothiolase; (10) phosphate acetyl transferase; $(11)$ acetate kinase

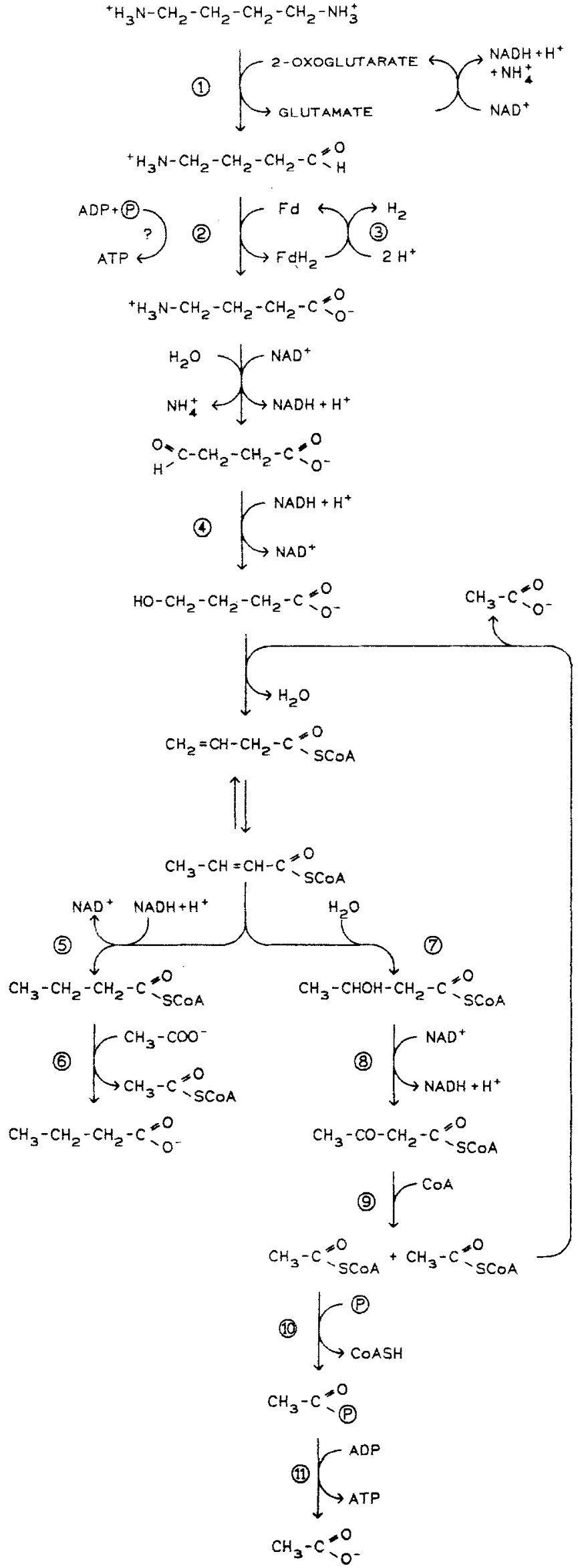


ever, butyrate formation could not be prevented completely indicating that the terminal crotonyl-CoA dismutation was not significantly affected by the hydrogen partial pressure.

The overall energy balance of putrescine fermentation according to Eq. (1) releases about $-107 \mathrm{~kJ}$ per mol putrescine, which would allow synthesis of more than $1 \mathrm{~mol}$ ATP per mol substrate (calculations after Thauer et al. 1977, and D'Ans and Lax 1983). The fermentation scheme in Fig. 4 in connection with Eqs. $(1-4)$ would allow per substrate level phosphorylation an overall synthesis of $0.5 \mathrm{ATP}$ per mol aminobutyrate or hydroxybutyrate, or of 1.15-1.3 ATP per mol of putrescine fermented, provided that the oxidation of aminobutyraldehyde is linked to ATP synthesis (see above). From experimentally determined cell yields $Y_{\text {ATP }}$ values of $2.5-4.6$ and $6.3-9.6 \mathrm{~g}$ per mol can be calculated with strains NorPut1 and MaPut1, respectively, which are low as compared to other bacteria (Stouthamer 1979). At present, we have no explanation for the significant difference in $Y_{\text {ATP }}$ values between these two strains.

\section{Taxonomy}

The new putrescine-degrading isolates are strictly anaerobic, Gram-positive, non-sporeforming bacteria. Physiologically, they resemble Clostridium aminobutyricum which also ferments 4-aminobutyrate to acetate and butyrate (Hardman and Stadtman 1960). However, Clostridium aminobutyricum sporulates and ferments many sugars (Hardman and Stadtman 1960) but not putrescine. Acetobacterium woodii, Clostridium barkeri and Eubacterium limosum form a systematically homogenous group of Gram-positive, nonsporeforming strict anaerobes which are related to each other by high homologies of their $16 \mathrm{~S}$ ribosomal RNAs (Tanner et al. 1981). They produce acetate or acetate and butyrate as fermentation products, and therefore resemble our new isolates. However, their DNA guanine-pluscytosine contents ( $39-48.3 \mathrm{~mol} \%)$ are considerably higher than that of our isolates $(29.6 \mathrm{~mol} \%)$, and therefore assignment to any of these genera is not possible either. A special feature of our strain NorPut1 is its unusual cell wall architecture. Most significantly, a second layer of periodically arranged subunits appears between the peptidoglycan layer and the cytoplasmic membrane. Occasionally, similar constructions of bacterial cell walls have been observed before with some Clostridium species (Sleytr 1976; Sleytr and Glauert 1976; Sleytr and Krebs 1971; Sleytr and Messner 1983, 1988), and with Bacillus sp. strain KL 1 (Wahlberg et al. 1987). For the clostridia it was assumed that the inner periodic protein layer is formed by reattachment of subunits (Sleytr 1976). With Bacillus sp. strain KL 1, the authors speculated whether the combination of the two periodic layers and the flagella might give rise for a moving apparatus enabling the cell to spread very fast on the surface of nutrient agar. With our strains, we did not observe spreading of this kind. Further work on the cell wall structure is needed before our isolates can be assigned correctly to a taxonomic entity.

Strain NorPut1 was deposited with the Deutsche Sammlung von Mikroorganismen, Braunschweig, under the number DSM 5092.

Acknowledgement. Part of this study was performed at the Department of Microbiology at the Philipps-Universität, Marburg. The authors are indebted to Prof. R. K. Thauer for stimulating discussions, and to the Fonds der Chemischen Industrie for financial support.

\section{References}

Bartholomew JW (1962) Variables influencing results, and the precise definition of steps in gram staining as a means of standardizing the results obtained. Stain Technology 37:139155

Bartsch RG, Barker HA (1961) A vinylacetyl isomerase from Clostridium kluyveri. Arch Biochem Biophys 92:122-132

Bergmeyer HU (1974) Methoden der enzymatischen Analyse, 3rd edn. Verlag Chemie, Weinheim

Blenden DC, Goldberg HS (1965) Silver impregnation stain for Leptospira and flagella. J Bacteriol 89:899-900

Brock TD (1979) Biology of microorganisms, 3rd edn. PrenticeHall, Englewood Cliffs, New Jersey

Chaney AL, Marbach EP (1962) Modified reagents for the determination of urea and ammonia. Clin Chem $8: 130-132$

Cline JD (1969) Spectrophotometric determination of hydrogen sulfide in natural waters. Limnol Oceanogr $14: 454-458$

D'Ans J, Lax E (1983) Taschenbuch für Chemiker und Physiker, Bd. 2, 4th edn. Springer, Berlin Heidelberg New York Tokyo

De Ley J, Cattoir H, Reynaerts A (1970) The quantitative measurement of DNA hybridization from renaturation rates. Eur J Biochem 12:133-143

Diekert G, Thauer RK (1978) Carbon monoxide oxidation by Clostridium thermoaceticum and Clostridium formicoaceticum. J Bacteriol 136:597-606

Hardman JK, Stadtman TC (1960) Metabolism of $\omega$-amino acids. I. Fermentation of $\gamma$-aminobutyric acid by Clostridium aminobutyricum n. sp. J Bacteriol 79:544-548

Hardman JK, Stadtman TC (1963) Metabolism of $\omega$-amino acids. IV. $\gamma$-Aminobutyrate fermentation by cell-free extracts of Clostridium aminobutyricum. J Biol Chem 238:2088-2093

Hilpert W, Schink B, Dimroth P (1984) Life by a new decarboxylation-dependent energy conservation mechanism with $\mathrm{Na}^{+}$ as coupling ion. EMBO J 3:1665-1670

Hollaus F, Sleytr UB (1972) On the taxonomy and fine structure of some hyperthermophilic saccharolytic clostridia. Arch Mikrobiol 86:129-146

Holmstedt B, Larsson L, Tham R (1961) Further studies of a spectrophotometric method for the determination of diamine oxidase activity. Biochim Biophys Acta 48:182-186

Karlson P (1984) Kurzes Lehrbuch der Biochemie, 12th edn. Thieme, Stuttgart

Kenealy WR, Waselefsky DM (1985) Studies on the substrate range of Clostridium kinyveri; the use of propanol and succinate. Arch Microbiol 141:187-194

Kim K (1964) Purification and properties of a diamine $\alpha$ ketoglutarate transaminase from Escherichia coli. J Biol Chem $239: 783-786$

Knoke M, Bernhardt H (1985) Mikroökologie des Menschen. Akademie-Verlag, Berlin, DDR

Lindner E (1986) Toxikologie der Nahrungsmittel, 3rd edn. Thieme, Stuttgart

Lynen F, Ochoa S (1953) Enzymes of fatty acid metabolism. Biochim Biophys Acta 12:299-314

Mandel M, Igambi L, Bergendahl J, Dodson ML jr, Scheltgen E (1970) Correlation of melting temperature and cesium chloride buoyant density of bacterial deoxyribonucleic acid. J Bacteriol $101: 333-338$

Moskowitz GJ, Merrick JM (1969) Metabolism of poly- $\beta$-hydroxybutyryl coenzyme A by an enoyl hydrase from Rhodospirillum rubrum. Biochemistry 8:2748-2755

Odom JM, Peck HD (1981) Localization of dehydrogenases, reductases, and electron transfer components in the sulfate-reducing bacterium Desulfovibrio gigas. J Bacteriol 147:161-169

Platen H, Schink B (1987) Methanogenic degradation of acetone by an enrichment culture. Arch Microbiol 149:136-141

Prieto-Santos MJ, Martin-Checa J, Balaña-Fouce R, GarridoPertierra A (1986) A pathway for putrescine catabolism in Escherichia coli. Biochim Biophys Acta 880:242-244 
Procházková L (1959) Bestimmung der Nitrate im Wasser. Z Anal Chem 167:254-260

Schink B (1984) Fermentation of 2,3-butanediol by Pelobacter carbinolicus sp. nov. and Pelobacter propionicus sp. nov., and evidence for propionate formation from $\mathrm{C}_{2}$ compounds. Arch Microbiol 137:33-41

Schink B, Pfennig N (1982) Fermentation of trihydroxybenzenes by Pelobacter acidigallici gen. nov. sp. nov., a new strictly anaerobic, non-spreforming bacterium. Arch Microbiol 133:195201

Sleytr UB (1976) Self-assembly of the hexagonally and tetragonally arranged subunits of bacterial surface layers and their reattachment to cell walls. J Ultrastruct Res 55:360-377

Sleytr UB, Glauert AM (1976) Ultrastructure of the cell wall of two closely related clostridia that possess different regular arrays of surface subunits. J Bacteriol 126:869-882

Sleytr UB, Glauert AM (1982) Bacterial cell walls and membranes. In: Harris JR (ed) Electron microscopy of proteins, vol 3. Academic Press, London, pp $41-76$

Sleytr UB, Krebs B (1971) Protoplastenbildung und Interpretation des Gefrierätzbildes der Membranstrukturen bei Clostridium nigrificans. Arch Mikrobiol 77:377-389

Sleytr UB, Messner P (1983) Crystalline surface layers on bacteria. Ann Rev Microbiol 37:311-339

Sleytr UB, Messner P (1988) Crystalline surface layers in procaryotes. J Bacteriol 170:2891 - 2897

Sleytr UB, Messner P, Pum D (1988) Analysis of crystalline bacterial surface layers by freeze-etching, metal shadowing, negative staining, and ultrathin sectioning. In: Mayer F (ed) Methods in microbiology, vol 20, Electron microscopy in microbiology. Academic Press, London, pp 29-60

Stadtman ER (1953) The coenzyme A transphorase system in Clostridium kluyveri. J Biol Chem 203:501-512

Stouthamer AG (1979) The search for correlation between theoretical and experimental growth yields. In: Quayle JR (ed) International review of biochemistry, microbial biochemistry, vol 21. University Park Press, Baltimore, pp $1-47$
Tanner RS, Stackebrandt E, Fox GE, Woese CR (1981) A phylogenetic analysis of Acetobacterium woodii, Clostridium barkeri, Clostridium butyricum, Clostridium lituseburense, Eubacterium limosum and Eubacterium tenue. Curr Microbiol 5:35-38

Tischer W, Bader J, Simon H (1979) Purification and some properties of a hitherto-unknown enzyme reducing the carbon-carbon double bond of $\alpha, \beta$-unsatured carboxylate anions. Eur J Biochem $97: 103-112$

Thauer RK, Jungermann K, Decker K (1977) Energy conservation of chemotrophic anaerobic bacteria. Bacteriol Rev 41:100180

Wahlberg J, Tynkkynen S, Taylor N, Uotila J, Kuusinen K, Kuusinen M, Häggblom M, Viljanen J, Villstedt R, NurmiahoLassila EL, Lounatmaa K (1987) A novel type of cell wall structure with two periodic layers (S-layer) of a Bacillus sp. strain KL1. FEMS Microbiol Lett 40:75 -79

Walther-Mauruschat A, Aragno M, Mayer F, Schlegel HG (1977) Micromorphology of Gram-negative hydrogen bacteria. Arch Microbiol 114: $101-110$

Widdel F, Pfennig N (1981) Studies on dissimilatory sulfate-reducing bacteria that decompose fatty acids. I. Isolation of new sulfate reducing bacteria enriched with acetate from saline environments. Description of Desulfobacter postgatei gen. nov., sp. nov. Arch Microbiol 129:395-400

Widdel F, Kohring GW, Mayer F (1983) Studies on dissimilatory sulfate-reducing bacteria that decompose fatty acids. III. Characterization of the filamentous gliding Desulfonema limicola gen. nov. sp. nov., and Desulfonema magnum sp. nov. Arch Microbiol 134:286-294

Zamenhoff S (1957) Preparation and assay of deoxyribonucleic acid from animal tissue. In: Colowick SP, Kaplan NO (eds) Methods in enzymology, vol 3. Academic Press, New York, pp 696-704

Received November 18, 1988/Accepted January 19, 1989 